(C) Group of authors, 2017

UDC 616.13-089-053.2

DOI - https://doi.org/10.14300/mnnc.2017.12073

ISSN - 2073-8137

\title{
METHODS OF MODIFIED ULTRAFILTRATION IN THE SURGICAL CORRECTION OF TRANSPOSITION OF THE GREAT ARTERIES IN NEWBORNS
}

\author{
Baizhigitov N. B. ${ }^{1,2}$, Ormantayev A. K. ${ }^{2}$, Sepbayeva A. D. ${ }^{2}$ \\ ${ }^{1}$ Center of Perinatology and Pediatric Cardiac Surgery, Almaty, Kazakhstan \\ 2 Kazakh National Medical University named after S. D. Asfendiyarov, Almaty, Kazakhstan
}

\section{МЕТОАЫ МОАИФИЦИРОВАННОЙ УАЬТРАФИАЬТРАЦИИ ПРИ ХИРУРГИЧЕСКОЙ КОРРЕКЦИИ ТРАНСПОЗИЦИИ МАГИСТРААЬНЫХ АРТЕРИЙ У НОВОРОЖАЕННЫХ АЕТЕЙ}

\author{
Н. Б. Байжигитов ${ }^{1,2}$, А. К. Ормантаев ${ }^{2}$, А. А. Сепбаева ${ }^{2}$ \\ 1 Центр перинатологии и Аетской карАиохирургии, Алматы, Казахстан \\ 2 Казахский национальный меАицинский университет им. С. А. АсфенАиярова, \\ Алматы, Казахстан
}

Correction of congenital heart defects in newborns in the cardiopulmonary bypass is accompanied by volumetric fluid overload. To eliminate this pathological condition an ultrafiltration method is used. The article presents the correction analysis of the years 2012-2016 to 20 newborns with transposition of the great arteries with the use of two methods of ultrafiltration during cardiopulmonary bypass: I group $(n=10)$ - ultrafiltration, II group $(n=10)$ - modified ultrafiltration after cardiopulmonary bypass stop. The findings suggest that in the group which underwent a modified ultrafiltration, the inotropic support index, the need for blood transfusion in the immediate postoperative period, the patient's time spent on mechanical ventilation was significantly lower than in the group of children which underwent ultrafiltration.

Keywords: transposition of great arteries, ultrafiltration, modified ultrafiltration

Коррекция врожденных пороков сердца у новорожденных детей в условиях искусственного кровообращения сопровождается объёмной перегрузкой жидкостью. Для устранения этого патологического состояния используется метод ультрафильтрации. Представлен анализ коррекции оперированных в 2012-2016 гг. 20 новорожденных с транспозицией магистральных артерий с использованием двух методов ультрафильтрации во время искусственного кровообращения: I группа $(\mathrm{n}=10)$ - ультрафильтрация, модифицированная ультрафильтрация после остановки искусственного кровообращения - II группа (n=10). Полученные данные свидетельствуют, что в группе, где выполнялась модифицированная ультрафильтрация, индекс инотропной поддержки, потребность в проведении гемотрансфузии в ближайшем послеоперационном периоде, время нахождения пациента на ИВЛ достоверно ниже, чем в группе детей с проводимой ультрафильтрацией.

Ключевые слова: транспозиция магистральных артерий, ультрафильтрация, модифицированная ультрафильтрация

$\mathrm{n}$ the world the number of operations carried out for congenital heart disease (CHD) is increasing each year, including those executed in the neonatal period [1].

One of the main intraoperative problems faced by an anesthesiologist and a perfusionist is the violation of child's hydrobalance and its correction. The causes of fluid overload may be the physiological characteristics of children (the physiological hydrophilic of fabric, the imperfection of kidneys functions, as well as their post-operative injury), conducting cardiopulmonary bypass (CB) (the mismatch of the circulating blood volume (CBV) of a child and the primary volume filling the circuit of the CB device, the introduction of exogenous fluids, the incompatibility of the CB circuit materials and the patient's blood, which in turn can trigger an enzyme cascade, which leads to the development of the capillary leak syndrome) $[3,15]$.

This pathological condition can be fixed by two methods of ultrafiltration: ultrafiltration (UF) during $\mathrm{CB}$ and modified ultrafiltration (MUF) $[6,8,9]$.
According to the literature, the positive ultrafiltration effects are: the reduction of myocardial edema, increased blood pressure, decreased heart rate, decreased central venous pressure, reduced need for inotropes $[7,11]$, improved oxygenation and reduction of extravascular lung water $[4,13]$, decrease in the severity of postperfusion systemic inflammatory response (reduction of plasma levels of proinflammatory cytokines), increased creatinine clearance and decreased total water content in the body [2, 10], increased hematocrit $(\mathrm{Ht})$ and coagulation factors in the plasma, thereby - reducing the use of transfusion media $[5,12,14]$.

There is an ongoing and intensive study of the use of ultrafiltration in the practice of child cardioanesthesiology. Our interest is to evaluate the effectiveness of ultrafiltration in combination of anesthetic management during the correction of transposition of the great arteries (TGA) in newborns. The purpose of the research is to evaluate the effectiveness of two methods of ultrafiltration in the correction of transposition of the great arteries in newborns. 
Material and Methods. The study included 20 neonatal patients with transposition of the great arteries operated on in the Center of Perinatology and Pediatric Cardiac Surgery from 2012 to 2016. All children underwent radical correction of TGA - Jatene Operation. All of the children were divided into two groups. The first group consisted of 10 patients who underwent UF during cardiopulmonary bypass, the second group - patients who underwent MUF after stopping CB.

The technique of UF during CB: blood collection from the aorta to the hemofilter by creating a vacuum in it up to $40 \mathrm{~mm}$ water column, at a rate of $20-50 \mathrm{ml} / \mathrm{min}$; blood returns were to the venous reservoir. UF volume in the first group was $52.7(33.1 ; 77.6) \mathrm{ml} / \mathrm{kg}$. The UF procedure was performed until the $\mathrm{Ht} 30 \%$.

The methodology of the MUF: after stopping CB blood was collected from the aorta to the hemofilter by creating a vacuum in it up to $40 \mathrm{~mm}$ water column, at a rate of $100-250 \mathrm{ml} / \mathrm{min}$; blood return were in the vena cava. MUF time was $13.5(11 ; 15)$ minutes. UF volume - 64.8 (50.0; $94.5) \mathrm{ml} / \mathrm{kg}$. The UF procedure was performed until the Ht $40 \%$

All patients underwent arterial switch of the main arteries in the conditions of artificial blood circulation (perfusion index to $2.5-3.2 \mathrm{~L} / \mathrm{min} / \mathrm{m}^{2}$ ) and moderate hypothermia $\left(32(31 ; 32)^{\circ} \mathrm{C}\right)$ with occlusion of the aorta, blood pharmaco-cholic cardioplegia.

Premedication in most cases was not used. Benzodiazepines (bryuzepam at a dose of $0.1-0.2 \mathrm{mg} / \mathrm{kg}$ ) were used to the children of older age given their emotional stresses and a strong fear of the operation.

Induction was performed by rapid «bolus» induction with sevoflurane followed by propofol $(2 \mathrm{mg} / \mathrm{kg})$, fentanyl $(5 \mathrm{mg} / \mathrm{kg})$, pipecuronium bromide $(0.1 \mathrm{mg} / \mathrm{kg})$, irrigation or nasotracheal intubation, mechanical ventilation with «Avance» machine by "General Electric» (USA) in the PSV mode. Infusion therapy was carried using Ringer's solution $+5 \%$ glucose solution at a rate of $4 \mathrm{ml} / \mathrm{kg} /$ hour, increasing when necessary the rate of infusion and using the colloidal solution (albumin, $10 \%$ ) depending on hemodynamic parameters. Systemic hypocoagulation was carried out using heparin at a dose of $3 \mathrm{mg} / \mathrm{kg}$, achieving 5 minutes before the aortic cannulation the activated clotting time (ACT) in the range of 460-600 seconds. Analgesia was carried out using in a total dose of $5 \mathrm{mg} / \mathrm{kg} / \mathrm{hour}$ before the skin incision stage, and additionally to this introduced $5 \mathrm{mg} / \mathrm{kg}$ of fentanyl before each skin incision and before sternotomy. Before $\mathrm{CB}$, in order to level the dilution effect, intravenously was used fentanyl $5 \mathrm{mg} / \mathrm{kg}$, pipecuronium bromide $0.1 \mathrm{mg} / \mathrm{kg}$. During perfusion, the administration of propofol and fentanyl continued in the previous dosages.

During the operation and in the postoperative period the following parameters were monitored: heart rate, invasive blood pressure, rectal temperature («Philips» monitor), the control of acid-base condition; perfusion balance, overall operating hemo-hydrobalance ( $\mathrm{ml})$; levels of Sp02 (\%) and lactate ( $\mathrm{mmol} / \mathrm{l})$, glucose during CB. All patients in the postoperative period for the purpose of analgesia infusion of fentanyl conducted at $3 \mathrm{mg} / \mathrm{kg}$. The criteria for possible extubation were clear consciousness without neurological deficit, stable performance of hemodynamics, adequate blood gases, no bleeding.

The dynamics of indicators of circulation and laboratory data were evaluated on eight stages: I - prior to surgery (baseline); II - prior to CB; III - after CB; IV - after the MUF; $\mathrm{V}$ - after surgery; $\mathrm{VI}-6$ hours after surgery; VII - 24 hours after surgery; VIII - 48 hours after surgery.

Statistical data processing was carried out using the statistical software package StatPlus Professional 5.8. In intergroup comparisons Wilcoxon T-test, U-test Mann Whitney were used. Results were considered authentic at the level of significance $p<0.05$. Results are presented as the median $(\mathrm{M})$ and percentiles $(25 ; 75)$.

Results and Discussion. The studied groups were comparable with respect to weight of patients, but differed significantly in age (Table 1). The inotropic support prior to operations needed $50 \%$ of the patients of the second group, unlike $10 \%$ in the first group. To assess the patient's need for inotropes we used the inotropic support index (IS) - the amount of dosage of cardiotonic drugs, $\mathrm{mg} / \mathrm{kg} / \mathrm{min}$, multiplied by a correction coefficient, which was equal to 1 for dopamine and dobutamine, and 100 for epinephrine and norepinephrine. After the correction of TMA the IS was significantly higher in the ultrafiltration group immediately after surgery and remained high at the end of the second day after surgery (Figure).

The distribution of children according

Table 1 to age and body weight

\begin{tabular}{|l|c|c|c|}
\hline Indicator & $\begin{array}{c}\text { UF group, } \\
\mathrm{n}=10\end{array}$ & $\begin{array}{c}\text { MUF group, } \\
\mathrm{n}=10\end{array}$ & $\mathrm{p}$ \\
\hline Age, days & $13.5(11.5 ; 15.0)$ & $10.0(9.5 ; 12.5)$ & $>0.05$ \\
\hline Weight, $\mathrm{kg}$ & $3.28(2.9 ; 3.87)$ & $3.33(2.97 ; 3.49)$ & $>0.05$ \\
\hline
\end{tabular}

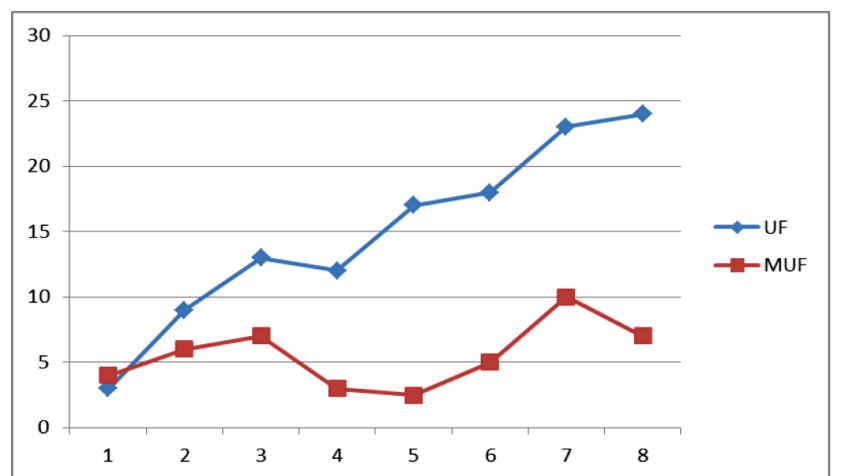

Fig. Inotropic support index: 1 - initially; 2 - before CB; 3 - after CB; 4 - after MUF; 5 - after operation; $6-6$ hours after operation; $7-24$ hours after operation; $8-48$ hours after operation

Ultrafiltration volume and moisture balance at the end of the $\mathrm{CB}$ was calculated in $\mathrm{ml} / \mathrm{kg}$. UF volume between the groups did not differ significantly, reaching 52.7 in the first group $(33.1 ; 77.6) \mathrm{ml} / \mathrm{kg}$, the second 64.8 (50.0; $94.5) \mathrm{ml} / \mathrm{kg}$. At the end of the CB, a negative hydro balance was received in the MUF group, and a positive one in the UF group. The hydro balance was positive by the end of the first postoperative day in both groups and did not differ between the groups. The infusion therapy during the first day was significantly different, and was 11.3 $(7.23 ; 14.45) \mathrm{ml} / \mathrm{kg} / \mathrm{h}$ in the first group, and 7.77 (6.67; $9.61) \mathrm{ml} / \mathrm{kg} / \mathrm{h}$ in the second group.

Groups did not differ in the level of hemoglobin and hematocrit before CB. After stopping CB and before the MUF procedure, the second group had much higher hemoglobin and hematocrit indicators comparing with the first group of patients. Drainage loss rate did not differ significantly between the groups (Table 2). The need for blood transfusions in the first day after the operation was $90 \%$ in the first group and $35 \%$ in the second group. Groups did not differ on the duration of $\mathrm{CB}$ and aortic clamping, but the duration of mechanical ventilation (MV) in the second group was significantly lower than in the first group. We also noted the tendency of a less length of stay of the patients on the second group in Intensive Care Unit (ICU) (Table 3). 
Intraoperative dynamics of hemoglobin and hematocrit, the rate of drainage losses of the first postoperative day

\begin{tabular}{|l|c|c|c|}
\hline Indicator & $\begin{array}{c}\text { UF group, } \\
\mathrm{n}=10\end{array}$ & $\begin{array}{c}\text { MUF group, } \\
\mathrm{n}=10\end{array}$ & $\mathrm{p}$ \\
\hline \multicolumn{4}{|c|}{ Hemoglobin, $\mathrm{g} / \mathrm{l}$} \\
\hline Initial & $144.5(123 ; 156)$ & $127(123 ; 143)$ & $>0.05$ \\
\hline After CB & $90.5(89 ; 110)$ & $137(113.5 ; 155.0)$ & $<0.05$ \\
\hline \multicolumn{4}{|c|}{ Hematocrit, \% } \\
\hline Initial & $40.5(34 ; 46)$ & $39.5(37.5 ; 39.5)$ & $>0.05$ \\
\hline After CB & $27.5(23 ; 30)$ & $39.5(32.5 ; 43.0)$ & $<0.05$ \\
\hline $\begin{array}{l}\text { Drainage } \\
\text { loss rate, } \\
\text { ml/kg/h }\end{array}$ & $\begin{array}{c}0.73 \\
(0.52 ; 1.97)\end{array}$ & $0.58(0.46 ; 1.04)$ & $>0.05$ \\
\hline
\end{tabular}

Influence of ultrafiltration on during the perioperative period

\begin{tabular}{|l|c|c|c|}
\hline \multicolumn{1}{|c|}{ Indicator } & $\begin{array}{c}\text { UF group, } \\
\mathrm{n}=10\end{array}$ & $\begin{array}{c}\text { MUF group, } \\
\mathrm{n}=10\end{array}$ & $\mathrm{p}$ \\
\hline $\begin{array}{l}\text { Duration of aor- } \\
\text { tic clamping, } \mathrm{min}\end{array}$ & $\begin{array}{c}50.5 \\
(44.5 ; 53.0)\end{array}$ & $61(49 ; 69)$ & $>0.05$ \\
\hline $\begin{array}{l}\text { Length of } \mathrm{CB}, \\
\text { min }\end{array}$ & $\begin{array}{c}85.5 \\
(79.5 ; 138.0)\end{array}$ & $107(99 ; 119)$ & $>0.05$ \\
\hline Length of MV, h & $\begin{array}{c}244.5 \\
(213 ; 336)\end{array}$ & $\begin{array}{c}124.5 \\
(90.5 ; 229.5)\end{array}$ & $<0.05$ \\
\hline $\begin{array}{l}\text { Length of stay } \\
\text { in ICU, } \mathrm{h}\end{array}$ & $\begin{array}{c}288 \\
(260 ; 333)\end{array}$ & $(128.5 ; 318.0)$ & 0.067 \\
\hline
\end{tabular}

\section{References}

1. Allen M., Sundararajan S., Pathan N., Burmester M., Macrae D. Anti-inflammatory modalities: their current use in pediatric cardiac surgery in the United Kingdom and Ireland. Pediatr. Crit. Care Med. 2009;10(3):341345. doi: 10.1097/PCC.0b013e3181a3105d

2. Draaisma A. M., Hazekamp M. G., Frank M., Anes N. Schoof P. H. [et al.] Modified ultrafiltration after cardiopulmonary bypass in pediatric cardiac surgery. Ann. Thorac. Surg. 1997;64(2):521-525. doi: 10.1016/ S0003-4975(97)00522-5

3. Francisco A. Portela, Alberto Pensado, Amelia Sánchez [et al.] A simple technique to perform combined ultrafiltration. Ann. Thorac. Surg. 1999;3(67):859-861. doi: org/10.1016/S0003-4975(98)01298-3

4. Gaynor J. W. Use of ultrafiltration during and after cardiopulmonary bypass in children. J. Thorac Cardiovasc Surg. 2001;122(2):209-211. doi: 10.1067/mtc.2001.115925

5. Gaynor J. W. The effect of modified ultrafiltration on the postoperative course in patients with congenital heart disease. Semin. Thorac. Cardiovasc. Surg. Pediatr. Card. Surg. Ann. 2003;6:128-139. doi: 10.1053/ pcsu.2003.50006

6. Harig F., Meier C., Hakami L., Strasser R., Bretzger J. [et al.] Does the additional use of heparin-coated extracorporeal circuits (ECC) optimize the effect of modified ultrafiltration (MUF) in pediatric perfusion? Thorac. Cardiovasc. Surg. 2006;54(3):168172. doi: $10.1055 / \mathrm{s}-2005-872863$

7. Keenan H. T., Thiagarajan R., Stephens K. E., Williams G., Ramamoorthy C. [et al.] Pulmonary function after modified venovenous ultrafiltration in infants: a prospective, randomized trial. The Journal of Thoracic and Cardiovascular Surgery. 2000;119:501-507. doi: 10.1067/ mtc.2000.103602

8. Magilligan D. J. Indications for ultrafiltration in the cardiac surgical patients. J. Thorac. Cardiovasc. Surgery. 1985;89(2):183-189. PMID:3968903
After radical correction of TMA the IS in the MUF group was significantly lower than in the first group where clinical heart failure is more pronounced. According to the literature, this is due to a decrease in myocardial edema after the MUF and the negative moisture balance [7].

According to our data, the use of MUF procedure significantly improves hemoglobin and hematocrit, thus reducing the need for erythrocyte mass transfusions. Besides, in our study, no significant differences in the drainage loss rate were detected [5].

The obtained results of significant reductions in the duration of artificial ventilation in the second group appears to be associated with the decrease of extravascular lung water, reduction of the total body water, and hence improved oxygenation [2, 4]. Against this background, it is possible to earlier adapt patients to the independent breathing.

\section{Conclusions:}

1. Both methods of hydrobalance regulation at TMA correction in $\mathrm{CB}$ conditions in newborns are effective and can eliminate anemia. However, using MUF after CB it is possible to reach the initial level of hemoglobin and hematocrit, and reduce the need for erythrocyte mass transfusions.

2. The use of MUF reduces post-operative heart failure, reduces the need for cardiotonic drugs, reduces the duration of postoperative mechanical ventilation and length of stay in the ICU.

9. Mahmoud A. B., Burhani M. S., Hannef A. A., Jamjoom A. A., Al-Githmi I. S. [et al.] Effect of modified ultrafiltration on pulmonary function after cardiopulmonary bypass. Chest. 2005;128(5):3447-3453. doi: 10.1378/ chest.128.5.3447

10. Naik S. K., Knight A., Elliot M. J. A successful modification of ultrafiltration for cardiopulmonary bypass in children. Perfusion. 1991;6(1):41-50. doi: 10.1177/026765 919100600106

11. Onoe M., Oku H., Kitayama H. [et al.] Modified ultrafiltration may improve postoperative pulmonary function in children with a ventricular septal defect. Surgery Today. 2001(31):586-590. doi: 10.1007/s005950170091

12. Ricci Z., Polito A., Netto R., De Razza F., Favia I. [et al.] Assessment of modified ultrafiltration hemodynamic impact by pressure recording analytical method during pediatric cardiac surgery. Pediatr. Crit. Care Med. 2013;14(4):390-395. doi: 10.1097/ PCC.0b013e31828a7113

13. Thompson L. D., McElhinney D. B., Findlay P., Miller-Hance W., Chen M. J. [et al.] A prospective randomized study comparing volume-standardized modified and conventional ultrafiltration in pediatric cardiac surgery. J. Thorac. Cardiovasc. Surg. 2001;122(2):220228. doi: $10.1067 /$ mtc.2001.114937

14. Yokoyama K., Takabayashi S., Komada T., Onoda K., Mitani Y. [et al.] Removal of prostaglandin E2 and increased intraoperative blood pressure during modified ultrafiltration in pediatric cardiac surgery. J. Thorac. Cardiovasc. Surg. 2009;137(3):730-735. doi: 10.1016/j. jtcvs.2008.09.017

15. Ziyaeifard M., Alizadehasl A Massoumi G. Modified UItrafiltration During Cardiopulmonary Bypass and Postoperative Course of Pediatric Cardiac Surgery. Res. Cardiovasc. Med. 2014;3(2):e17830. doi: 10.5812/cardiovascmed. 17830

\section{About authors:}

Baizhigitov Nurlan Bolatovich, MD, Assistant at the Department of Cardiovascular Surgery

tel.: +77004712472; e-mail: nurlan.baizhigitov@mail.ru

Ormantayev Almas Kamalovich, MD, DMSc, Professor, Head of the Department of Pediatric Surgery; tel.: +77017120057; e-mail: a_kamalovich@mail.ru

Sepbayeva Anar Duisenovna, MD, DMSc, Assistant professor of pediatric surgery; tel.: +77052201231; e-mail: s.anar72@mail.ru 